\title{
Review
}

Pathobiology

\section{Current Concepts of Enzyme Histochemistry in Modern Pathology}

\author{
William A. Meier-Ruge Elisabeth Bruder \\ Institute of Pathology, University Hospital Basel, Basel, Switzerland
}

\begin{abstract}
Key Words
Enzyme histochemistry · Experimental pathology • Pathobiological techniques - Hirschsprung disease • Brain infarct $\cdot$ Dehydrogenase $\cdot$ Alkaline phosphatase $\cdot$ Acid phosphatase $\cdot$ Acetylcholinesterase
\end{abstract}

\begin{abstract}
Enzyme histochemistry serves as a link between biochemistry and morphology. It is based on metabolization of a substrate provided to a tissue enzyme in its orthotopic localization. Visualization is accomplished with an insoluble dye product. It is a sensitive dynamic technique that mirrors even early metabolic imbalance of a pathological tissue lesion, combined with the advantage of histotopographic enzyme localization. With the advent of immunohistochemistry and DNA-oriented molecular pathology techniques, the potential of enzyme histochemistry currently tends to be underrecognized. This review aims to draw attention to the broad range of applications of this simple, rapid and inexpensive method. Alkaline phosphatase represents tissue barrier functions in brain capillaries, duodenal enterocyte and proximal kidney tubule brush borders. Decrease in enzyme histochemical alkaline phosphatase activity indicates serious functional impairment. Enzyme histochemical increase in lysosomal acid phosphatase activity is an early marker of ischemic tissue lesions. Over the last four decades, acetylcholinesterase enzyme histochemistry has proven to be the gold standard for the diagnosis of Hirschsprung disease and is
\end{abstract}

one of the most commonly applied enzyme histochemical methods today. Chloroacetate esterase and tartrate-resistant phosphatase are both resistant to formalin fixation, EDTA decalcification and paraffin embedding. Early enzyme histochemical insight into development of a pathologic tissue lesion and evaluation of function and vitality of tissue enhance our understanding of the pathophysiology of diseases. In this process, enzyme histochemistry constitutes a valuable complement to conventional histology, immunohistochemistry and molecular pathology for both diagnostic and experimental pathology.

Copyright $\odot 2008$ S. Karger AG, Basel

\section{Introduction}

Enzyme histochemistry is a morphological technique applied to functional questions in histopathology (fig. 1). Enzyme histochemistry constitutes a link between biochemistry and morphology $[1,2]$ and provides important information complementary to conventional histology, immunohistochemistry and molecular pathology.

The father of enzyme histochemistry was A.G.P. Pearse $[3,4]$. Since the initial introduction of enzyme histochemistry, reactions involving almost all enzymes known have been applied to sections of any human tissue. It was applied in the diagnosis of peracute myocardial infarction $[5,6]$, the diagnosis of celiac disease [7-15], of brain

\section{KARGER \\ Fax +4161306 1234 \\ E-Mail karger@karger.ch}

www.karger.com
(C) 2008 S. Karger AG, Basel

$1015-2008 / 08 / 0754-0233 \$ 24.50 / 0$

Accessible online at:

www.karger.com/pat
Dr. med. Elisabeth Bruder

Institute of Pathology, University Hospital Basel

Schönbeinstrasse 40

$\mathrm{CH}-4031$ Basel (Switzerland)

Tel. +41 6126520 22, Fax +41 6126531 94, E-Mail elisabeth.bruder@unibas.ch 


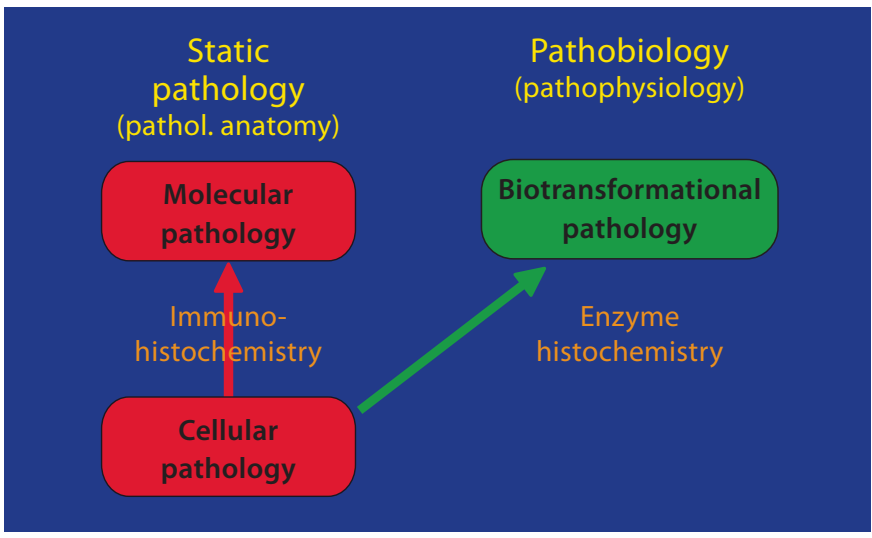

Fig. 1. Schematic representation of conventional stains (left) set against enzyme histochemistry (right). Both techniques function as complements, but show different tissue characteristics: (1) conventional $\mathrm{HE}$ stain delineates the different tissue compartments; (2) enzyme histochemistry highlights functional alterations. It is a tool to elucidate the pathophysiology of a particular disease, as for example disturbance of blood-brain barrier with decrease in capillary alkaline phosphatase in the brain, therapy resistance to anticancer treatment with increase in glycolytic turnover in breast cancer.

lesions [16-19], and in tumor treatment [20-30], to name only a few examples.

Traditionally, chloroacetate esterase and tartrate-resistant acid phosphatase have been developed for assessment of myelopoiesis and osteoclastogenesis, respectively [31-37].

Currently, besides lactic dehydrogenase and succinic dehydrogenase in the neuropathological investigation of muscle biopsies, acetyl cholinesterase remains the most commonly performed enzyme histochemical reaction in a standard pathology laboratory $[38,39]$.

After widespread application of enzyme histochemistry up to the 1970s, immunohistochemistry rapidly gained territory. Immunohistochemistry then arose as a new technique, and is now widely applicable to standard paraffin-embedded specimens in pathology, opening vast possibilities for tumor diagnosis and research. Furthermore, with the advent of molecular pathology, the potential of enzyme histochemistry is currently underestimated.

The aim of this review is to show in a number of essential examples, which causative mechanisms can be elucidated by enzyme histochemistry. This method is not limited to the diagnosis of Hirschsprung disease [40] but permits early insights into a range of different pathological processes [39].

\section{General Principles of Enzyme Histochemical Techniques}

Enzyme histochemistry combines the biochemical analysis of enzyme activity with information on its topographical localization. The basic techniques of enzyme histochemistry are described in detail in the laboratory manuals of Pearse [4], Meier-Ruge et al. [38], Meier-Ruge and Bruder [40] and Lojda and Schiebler [41]. In order to briefly acquaint the reader unfamiliar with these techniques, we describe two of the most important enzyme histochemical techniques in detail.

In a dehydrogenase reaction, enzyme substrates like sodium succinate or sodium L-lactate are oxidized and a stoichiometric color indicator tetranitrotetrazolium chloride blue (TNBT) is reduced to black or blue formazan. The formazan immediately binds to local protein and permits the precise localization of the enzyme dehydrogenase in a particular tissue compartment. The enzyme histochemical reaction follows the stoichiometric principles of biochemistry. Whereas biochemistry is applied to tissue homogenates or extracts, expressing enzyme activity in turnover rates, enzyme histochemistry indicates the locus of an enzyme in the tissue section.

A second group of enzyme reactions use diazonium salt instead of tetrazolium chloride as color indicator. Enzymes stained with this kind of reaction are mainly esterases and phosphatases. The ester group or phosphate group of a naphthyl salt is split off by the enzyme reaction and the naphthyl rest couples to a diazo-salt and stains the esterase- or phosphatase-containing compartment like in a formazan color reaction [38, 41-43].

Almost all enzyme histochemical investigations are performed with frozen tissue, because most enzymes are inactivated by formalin fixation. In fact, formalin fixation is even employed to stop enzyme histochemical reactions like lactic dehydrogenase or succinic dehydrogenase reactions [40]. With the requirement of frozen tissue, transportation and storage of biopsies or surgical specimens become an issue and lead to frequently asked questions in daily routine practice. It is recommended to freeze specimens on dry ice $\left(\mathrm{CO}_{2}\right)$ at $-80^{\circ} \mathrm{C}$ or in isopentane stored in $\mathrm{a}-25^{\circ} \mathrm{C}$ freezer. Liquid nitrogen carries the disadvantage of cracking freezing artifact in large tissue specimens [43]. After freezing as described, the tissue can be stored without loss of enzymatic activity for longer periods at $-25^{\circ} \mathrm{C}$ in a small Eppendorf tube (biopsies) or plastic bag (surgical resections).

Similarly, an important technical point to stress is the minimal section thickness. It is recommendable to cut 
cryostat sections at $15 \mu \mathrm{m}$ in order to overcome the minimal enzyme activity threshold for the enzymatic starting reaction [43]. It is important to be aware that a 15$\mu \mathrm{m}$-thick cryostat section loses $70 \%$ of its thickness by thawing, spreading and drying, resulting in a final thickness of $4 \mu \mathrm{m}$, whereas an originally 4 - $\mu \mathrm{m}$-thick native cryostat section has a final thickness of $1.2 \mu \mathrm{m}$, so that in thin sections the enzyme reaction does not reliably develop because the enzyme activity may drop below the enzymatic starting reaction [43].

\section{Enzyme Histochemistry versus Biochemical Analysis}

Biochemistry employs tissue extracts or tissue homogenates. Analysis of such tissue specimens reveals a general increase or decrease in enzyme activity measured in turnover rates. In contrast, enzyme histochemistry localizes enzyme activity to cells or tissue compartments but does not provide the exact quantitative data of biochemical analysis. The capability to localize enzyme histochemical activity on a cellular level justifies the Greek prefix '-topo' in the term 'enzyme histotopochemistry', distinguishing enzyme histochemistry from biochemistry.

Overall, there is a good correlation between histochemically judged enzyme activity per volume (area $\times$ thickness) and biochemically determined activity per milligram tissue [1].

The strength of biochemistry lies in the potential for quantification: biochemistry permits exact quantification of enzymatic turnover rates, whereas enzyme histochemistry has the disadvantage of a lack of reliable quantification, so that only semiquantitative assessment is achieved if microspectrophotometry is applied. However, the elective staining of a particular tissue structure in enzyme histochemistry permits precise morphometric size measurement by means of optic electronic morphometry equipment, e.g. the ASBA3 system [44] (compare fig. 15 and 16). The level of monochromic light absorption permits semiautomatic calculation, e.g. of the extension of an ischemic brain infarct. Another example of morphometric analysis in conjunction with enzyme histochemistry is the determination of nerve cell size, nerve cell number and nerve cell distance of the myenteric plexus stained with lactic dehydrogenase enzyme histochemistry [40] (compare fig. 5).

Biochemistry incurs the disadvantage of tissue dilution effect by tissue surrounding the structure of interest. Chromatography, electrophoresis or density gradient

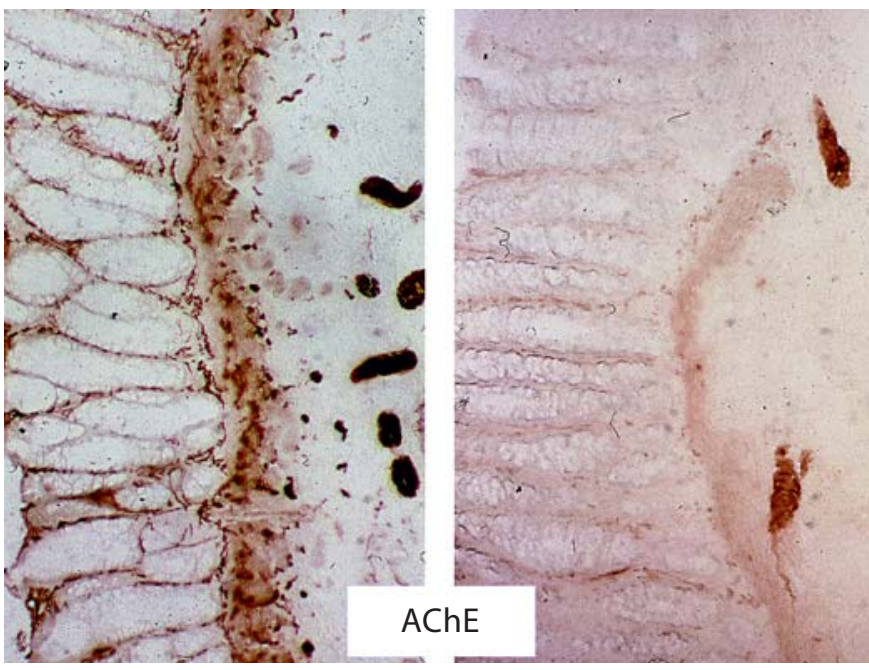

Fig. 2. Hirschsprung disease with characteristic increase in acetylcholinesterase activity in parasympathetic nerve fibers of muscularis mucosae and lamina propria mucosae (left), compared to normally innervated rectum mucosa (right). $\times 90$. The increased unmodulated release of acetylcholine from the sacral roots S2-S5, due to aplasia of nerve cells of the enteric nervous system in the rectum, leads to elevation of acetylcholinesterase activity as a reliable diagnostic parameter.

centrifugation is applied to compensate for this disadvantage. Compared to enzyme histotopochemistry, the biochemical procedure is therefore time-consuming but nevertheless falls short to localize the altered structure, which is more easily demonstrated by enzyme histotopochemical means.

\section{Applications of Enzyme Histochemistry as a Tool in Diagnostic Pathology and Pathobiology}

Enzyme histochemistry can be used in pathohistological routine diagnosis as it has simple technical requirements. Enzyme histotopochemical demonstration of acetylcholinesterase activity in frozen colon mucosal biopsies has proven a reliable tool and is the current gold standard in the diagnosis of Hirschsprung disease today [2, 40, 45-48] (fig. 2). In particular, in the diagnosis of ultrashort Hirschsprung disease and aganglionosis limited to the internal sphincter, the so-called sphincter achalasia, the acetylcholinesterase reaction is the choice technique [49-52].

Another attractive application of enzyme histochemistry is the verification of a peracute myocardial infarction during autopsy. This can be performed macroscopi- 


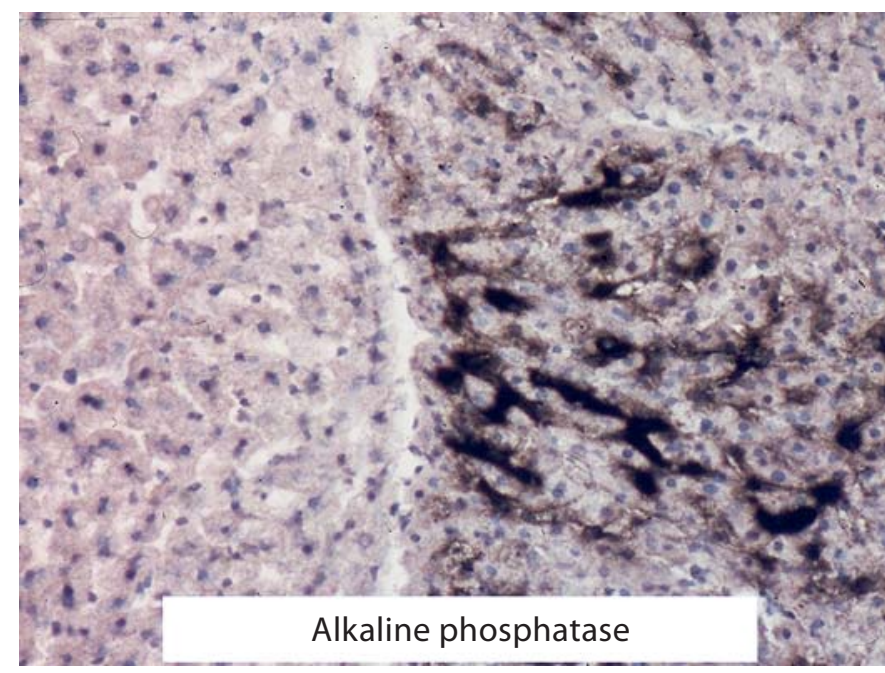

Fig. 3. Liver in burn shock with impaired elimination of alkaline phosphatase (right). Normal liver (left) as depicted in an alkaline phosphatase reaction. Hemalum counterstain. $\times 60$.
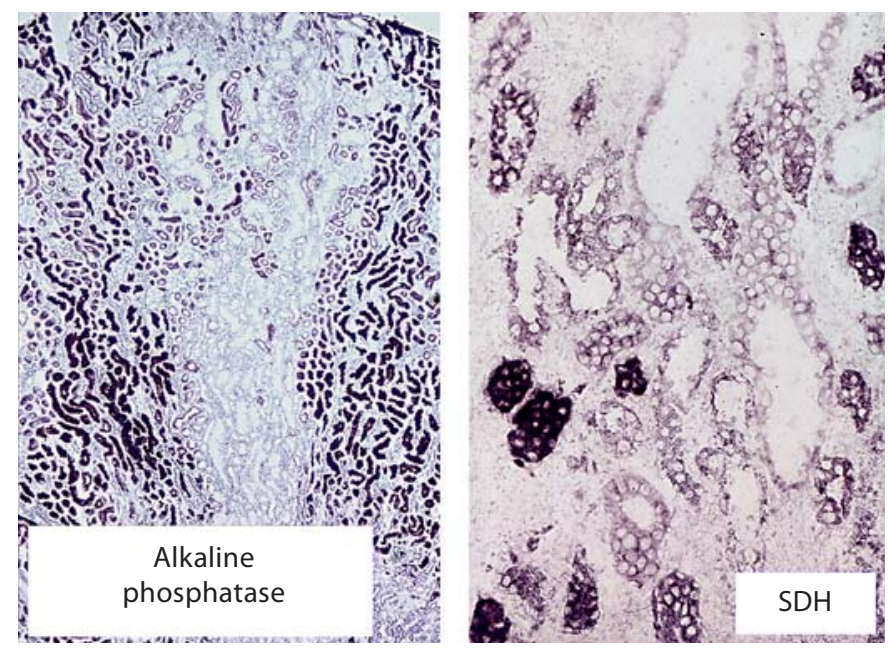

Fig. 4. Toxic kidney injury in rat due to 5,7-dichloro-8-hydroxychinaldine. Left: focal decrease in alkaline phosphatase reaction of the brush border in the proximal renal tubule. $\times 60$. Right: focal decrease in succinic dehydrogenase activity in distal renal tubule epithelium (disturbed reabsorption of primary urine). $\times 250$.

cally by a succinic dehydrogenase reaction in a Petri dish with succinate (13 $\mathrm{g}$ in $100 \mathrm{ml}$ phosphate buffer at $\mathrm{pH} 7.4$ ) and neotetrazolium chloride (100 mg dissolved in phosphate buffer). The reduced succinic dehydrogenase activity in the ischemic area of the myocardial infarction

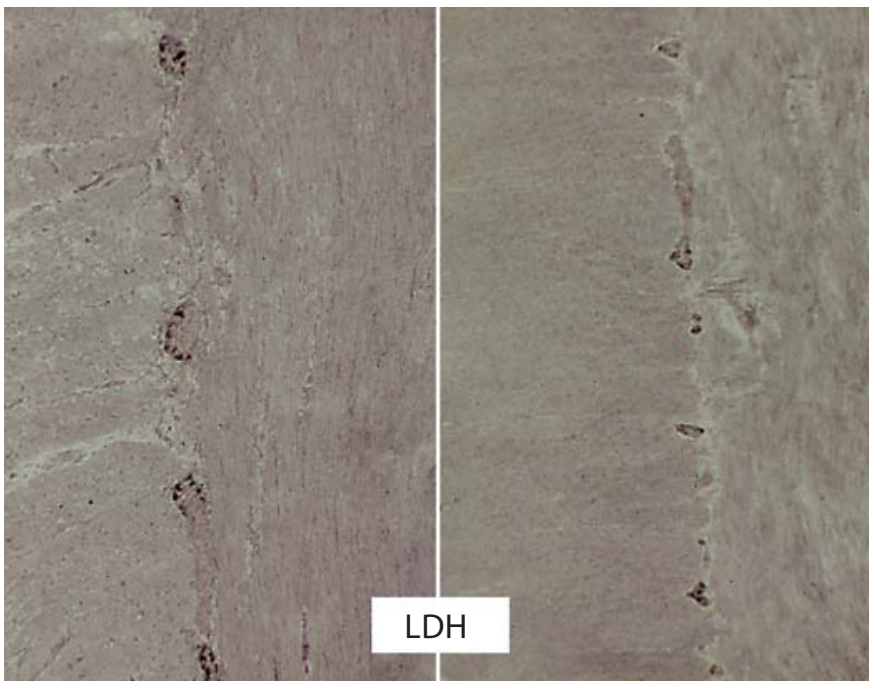

Fig. 5. Hypoganglionosis of myenteric plexus (right). Normal myenteric plexus (left). Lactic dehydrogenase reaction. $\times 160$. Hypoganglionosis is a common cause of chronic constipation. can quickly and reliably be recognized macroscopically $[5,6]$.

The enzyme alkaline phosphatase conveys a range of important information. On the one hand, alkaline phosphatase is eliminated by bile secretion. An increase or accumulation of alkaline phosphatase in bile capillaries of the liver indicates a disturbed mechanism of secretion [53-57] (fig. 3). Toxic lesions of the liver, infectious hepatitis [58-60] or seriously congested liver [57, 61] show similar pictures. These observations demonstrate that a simple enzyme histochemical reaction for alkaline phosphatase indicates a functional disturbance of the liver in biopsy or autoptic liver tissue. In addition to the transport function of bile capillaries for alkaline phosphatase, this enzyme represents a barrier function and is observed in structures with directed transport function. Alkaline phosphatase of brain capillaries represents the bloodbrain barrier [39, 62, 63].

The alkaline phosphatase of the brush border of the proximal renal tubules is responsible for absorption of metabolites from the primary urine and is quite sensitive to toxic or ischemic injury [64-66] (fig. 4).

Of particular diagnostic value is alkaline phosphatase in the brush border of the duodenal mucosa in the diagnosis of celiac disease. Alkaline phosphatase activity is high in young adults and low in postweaning children [7]. This enzyme is a fairly sensitive parameter in the diagnosis and therapy of celiac disease. Similarly, malabsorption 
syndromes show loss of alkaline phosphatase in the brush border of enterocytes [8-12]. The reappearance of an alkaline phosphatase brush border of enterocytes in duodenal mucosal biopsies is a clear indicator of compensated celiac disease. It is a parameter superior to the histological findings of villous atrophy. With the progression of celiac disease, the dehydrogenase activity of enterocytes decreases [46]. The tremendous number of publications illustrates the diagnostic and therapeutic difficulties of celiac disease [13-15].

Examination of seromuscular biopsies or resected specimens with lactic, succinic dehydrogenase and nitroxide synthetase reactions permitted the morphometric characterization of hypoganglionosis as a cause of chronic constipation $[67,68]$. Proximal to the aganglionic segment, often, a hypoganglionic segment is observed with scanty nerve cells and ganglia with increased interganglionic distances [40, 69] (fig. 5). The hypoganglionic segment shows a decreased acetylcholinesterase activity in the muscularis propria, indicating disturbed motility (fig. 6). Over recent years, enzyme histotopochemistry has contributed to remarkably improved understanding of the pathophysiology of chronic constipation [40].

Dehydrogenase reactions are of interest to examine the vitality of a particular tissue. In kidney biopsies, not only alkaline phosphatase is of interest but also the dehydrogenase activity of the tubulus epithelium [64-66] (fig. 4). The latter demonstrates the vitality of the kidney, which may be of interest in transplanted kidneys.

In oncology, dehydrogenase activity of a tumor demonstrates its vitality with the impact on the efficiency of cytostatic therapy or radiotherapy. Is has been clearly shown that tumor tissue with high glycolytic activity is particularly resistant to radiotherapy $[20,70,71]$. High glycolytic tumor activity is revealed in enzyme histochemistry for succinic and lactic dehydrogenase (fig. 7). Enzyme histochemistry for dehydrogenase provides a quick, efficient and inexpensive orientation on the actual energy metabolism of a particular tumor and on the expected efficacy of the therapeutic strategy $[21,22]$. This opens a fascinating field of research in monitoring cancer treatment. Glycolytic inhibitors, depriving cancer cells of their energy supply, are under discussion for a new class of anticancer drugs [23-25], and it has recently been demonstrated that cancer cells with high glycolytic rate [26$28]$ are characterized by high drug resistance [27-30].

Craniocerebral trauma and temporary ischemia is often hard to prove in a hemalum-eosin stain. Enzyme histochemistry shows a significant decrease in lactic and

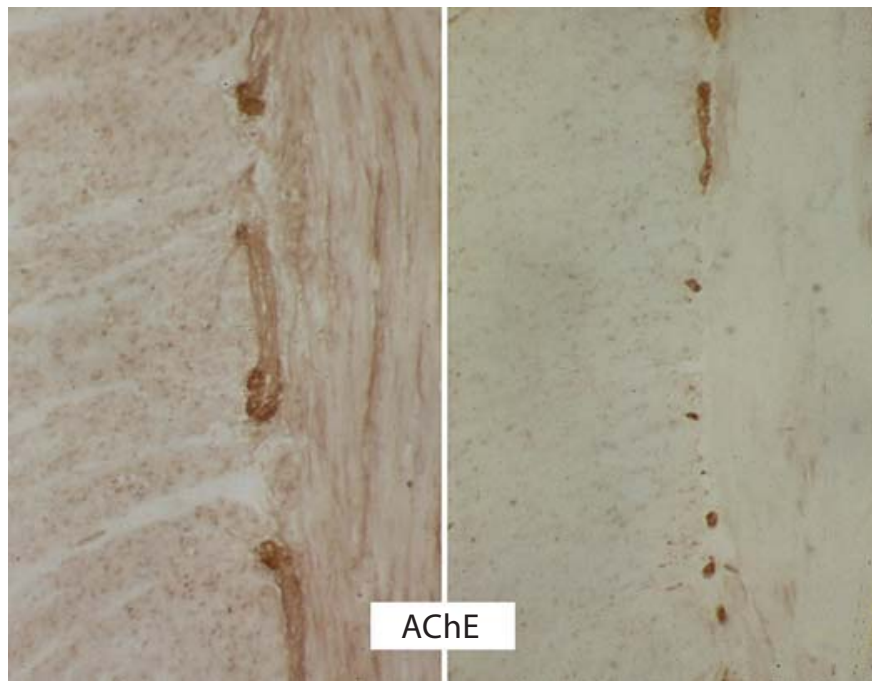

Fig. 6. Right: Hypoganglionosis of myenteric plexus shown in an acetylcholinesterase reaction with low enzyme activity in circular muscle layer of the muscularis propria. Low acetylcholinesterase activity is an indicator of disturbed colon motility. Left: Normal myenteric plexus and acetylcholinesterase activity in circular muscle layer in a patient with normal motility. $\times 180$.

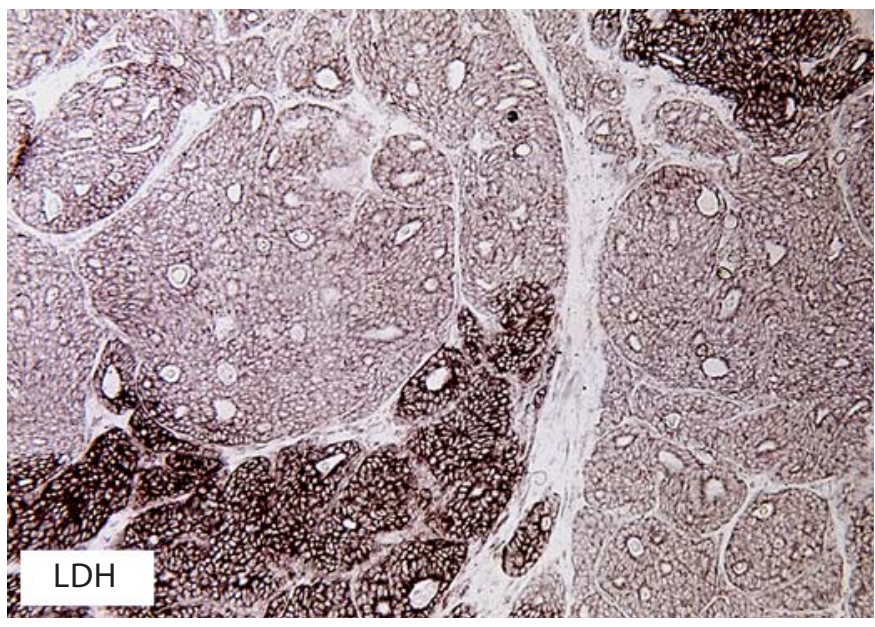

Fig. 7. Breast cancer with focal decrease in lactic dehydrogenase activity as a result of radiotherapy. $\times 60$. Enzyme histochemistry of glycolytic enzymes of tumor biopsies permits an evaluation of anticancer therapy.

succinic dehydrogenase activity in Purkinje cells of the cerebellum under these conditions (fig. 8). Lesions of blood-brain barrier are characterized by focal or diffuse decrease in alkaline phosphatase in brain capillaries [72, 73] (fig. 9). This kind of brain lesions can be observed in 

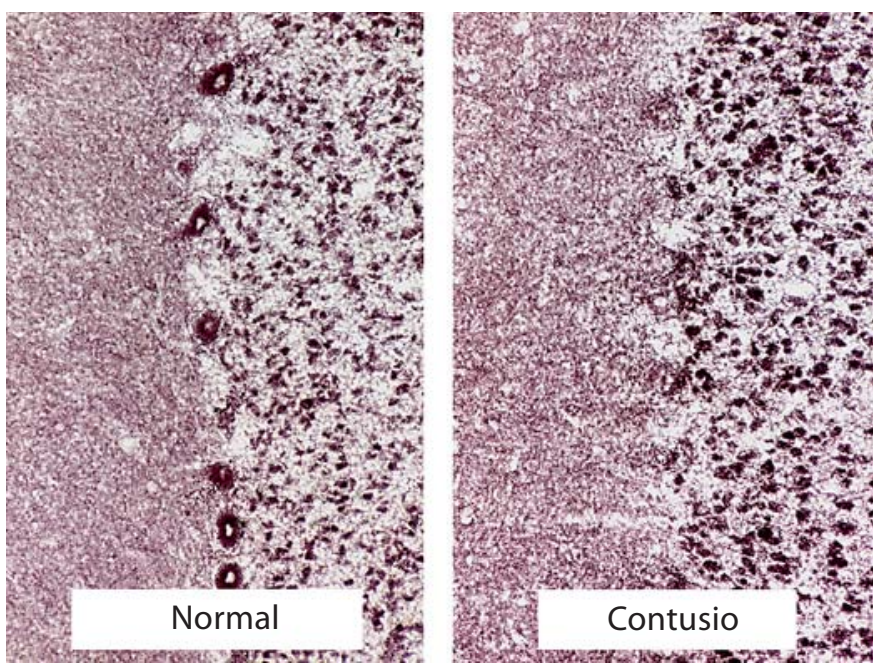

Fig. 8. Cerebellum with contusio. Decrease of lactic dehydrogenase activity in Purkinje cells (right) in comparison to normal cerebellum (left). $\times 180$.

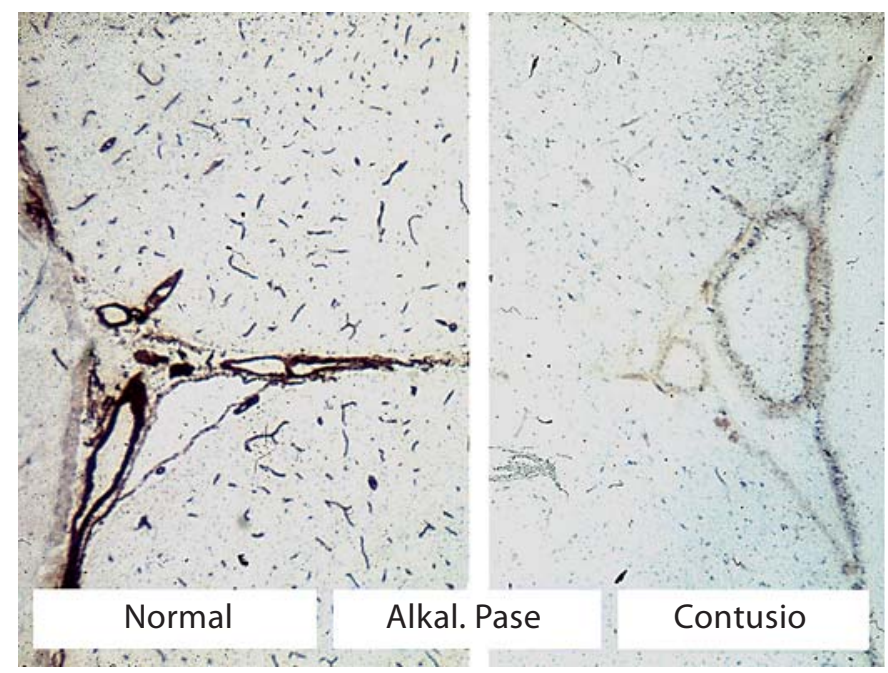

Fig. 9. Brain edema after contusio cerebri. Disturbed blood-brain barrier with decreased capillary alkaline phosphatase activity (right) and normal capillary net (left). $\times 50$.

boxers [16]. Only few papers in the literature deal with these particular lesions [17-19]. The brain is particularly suited for a postmortem enzyme histochemical examination, because autolytic processes start fairly late in the adult brain.

Senile plaques in the brain can be electively highlighted by their intense acid phosphatase activity (fig. 10). Acid phosphatase is a key enzyme of lysosomal activity.
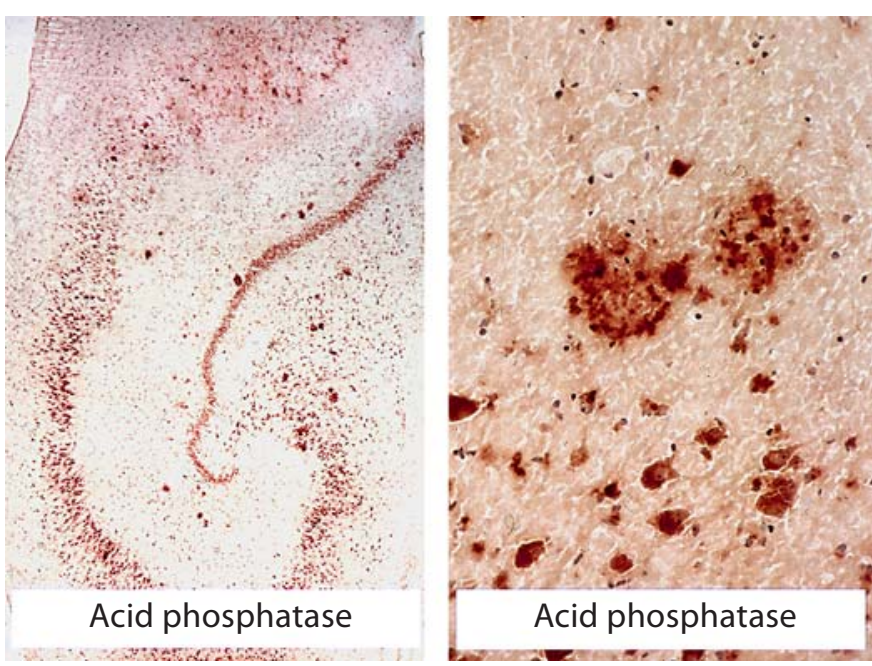

Fig. 10. Senile plaques stained with acid phosphatase in the dentate gyrus of hippocampus $($ left; $\times 120)$ and higher magnification (right; acid phosphatase without counterstain; $\times 400$ ).

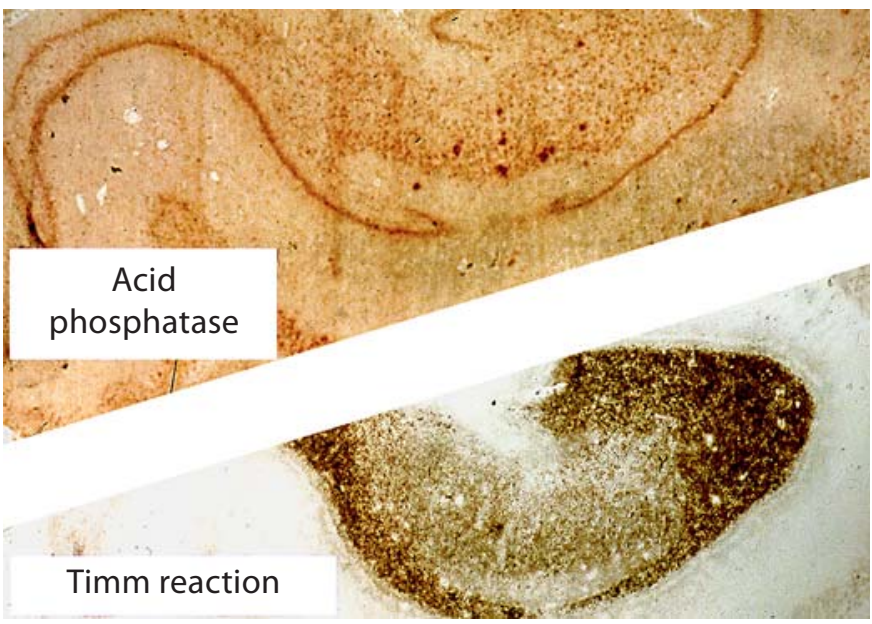

Fig. 11. Decrease in synaptic density as visualized with a Timm reaction in vicinity of senile plaques (dentate gyrus of hippocampus). $\times 120$. Timm reaction and acid phosphatase reactions are performed in consecutive serial sections. The Timm reaction was developed to visualize structures like axons and is currently applied in experimental pathology research [82]. The Timm reaction shows that senile plaques are associated with a dropout of specific neuronal structures in the area of plaque formation.

The combination of an acid phosphatase reaction with a Timm staining reveals a decrease of synapses in the surroundings of senile plaques in the hippocampus (fig. 11). Lysosomal enzymes may be responsible for the formation of senile plaques [74]. 


\section{Applications of Enzyme Histochemistry in Experimental Pathology}

Enzyme histochemical investigations on causes of intoxication, drug side effects or a particular disease are usually performed in laboratory animals. Enzyme histochemistry permits monitoring of a dose-dependent intoxication and time-related changes in different organs of rats, mice, dogs, cats and other laboratory animals.

Cats as twilight animals with nocturnal activity have a retina rich in rods. Such retinas have a particularly high metabolism of the visual cells and a high sensitivity to toxic side effects. The thioridazine analogue piperidylchlorophenothiazine caused night blindness and pigmentation of the retina in clinical trials with high dosage of the tranquilizer. In laboratory cats, it was possible to demonstrate that piperidylchlorophenothiazine inhibits glycolytic enzyme activity of rods (fig. 12), accompanied by an increased desquamation of peripheral rod segments. Phagocy tosis and storage of these light absorbing structures from the rods in the pigment epithelium causes pigmentation of the cat retina [75]. Elucidation of this drug side effect was rendered possible by enzyme histochemical analysis.

The chloroquinone retinopathy is characterized by a toxic edema of the pigment epithelium [76, 77] (fig. 13). This implies a defect of the visual field of the retina [77], because pigment epithelium is not further able to isomerize all-trans retinine to 11-cis retinine which is necessary for rhodopsin synthesis. The reason of this localized side effect of chloroquine in the retina is its accumulation on choroid melanin and high chloroquine levels in the vitreous fluid damaging the pigment epithelium.

The development of an ischemic brain infarct by experimental occlusion of the middle cerebral artery in primates was studied with the lysosomal enzyme acid phosphatase. In this trial, the time-dependent increase in the ischemic brain infarct was studied [78] (fig. 14). A circulatory arrest in neonatal pigs demonstrated the earliest morphological changes after $90 \mathrm{~min}$ [78]. In primates, the release of acid phosphatase starts immediately after clipping the medial cerebral artery. The extension of the ischemic brain infarct becomes obvious 20-30 min later. Acid phosphatase permits a morphometric, time-dependent follow-up of the extension of the infarct size [78-80] (fig. 15). Morphometric measurements of alkaline phosphatase-positive capillaries in combination with the size of the ischemic infarct show that the therapeutic window for an effective infarct treatment is limited to the first $4 \mathrm{~h}$ with declining time-dependent effectiveness [78, 81].
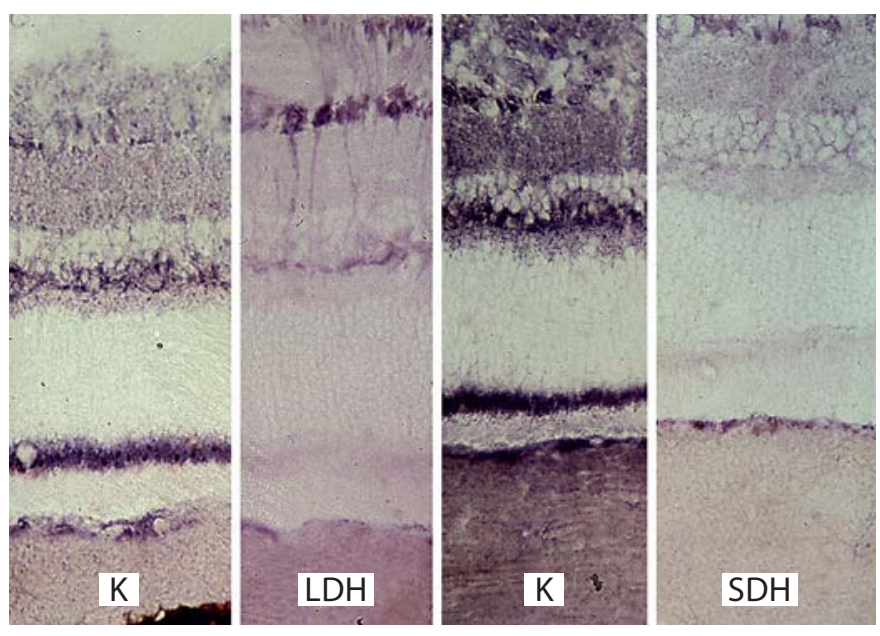

Fig. 12. Cat retina with inhibition of dehydrogenase activity in the ellipsoids of rods by experimental phenothiazine retinopathy (left) in comparison with normal retina (right). Lactic and succinic dehydrogenase. $\times 120$. The decrease in dehydrogenase activity in rod ellipsoids is accompanied by an increased desquamation of peripheral rod segments with the consequence of night blindness.
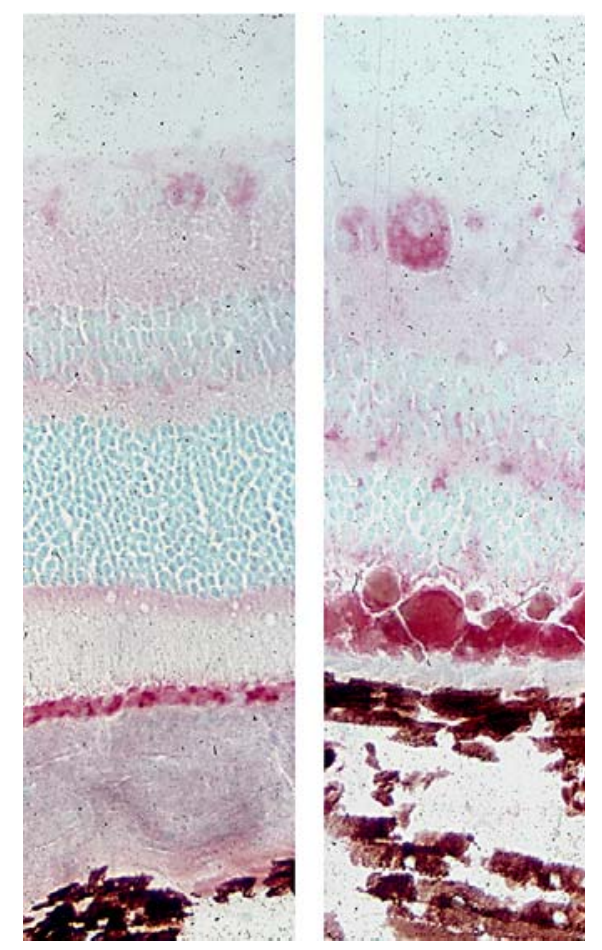

Fig. 13. Right: Chloroquine retinopathy with toxic edema of pigment epithelium (brown/red color), which blocks the isomerization of all-trans retinine to II-cis retinine, thereby decreasing the visual field of the affected eye. Left: normal retina, acid phosphatase (brown/red color) with light green counterstain. $\times 240$. 

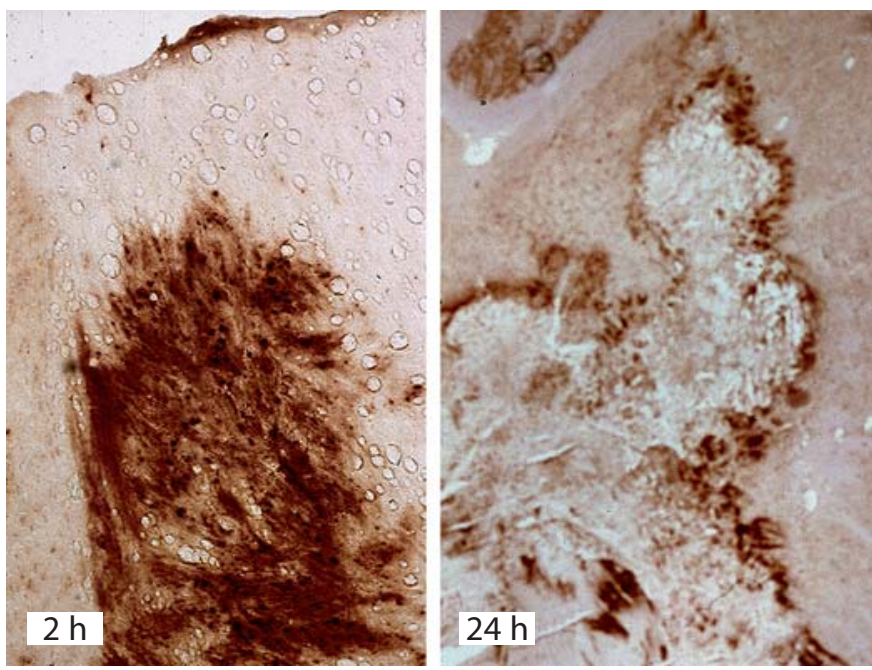

Fig. 14. Ischemic brain infarct in a primate brain (acid phosphatase reaction). In the first $2 \mathrm{~h}$ (left), only a release of lysosomal acid phosphatase is observed without manifest necrosis. After $24 \mathrm{~h}$ (right; $\times 60$ ), extensive necrosis is established, and acid phosphatase is only observed at the border between necrosis and surrounding brain tissue. This distinct staining of the ischemic area permits optimal semiautomated morphometric measurement, as represented in figures 15 and 16.

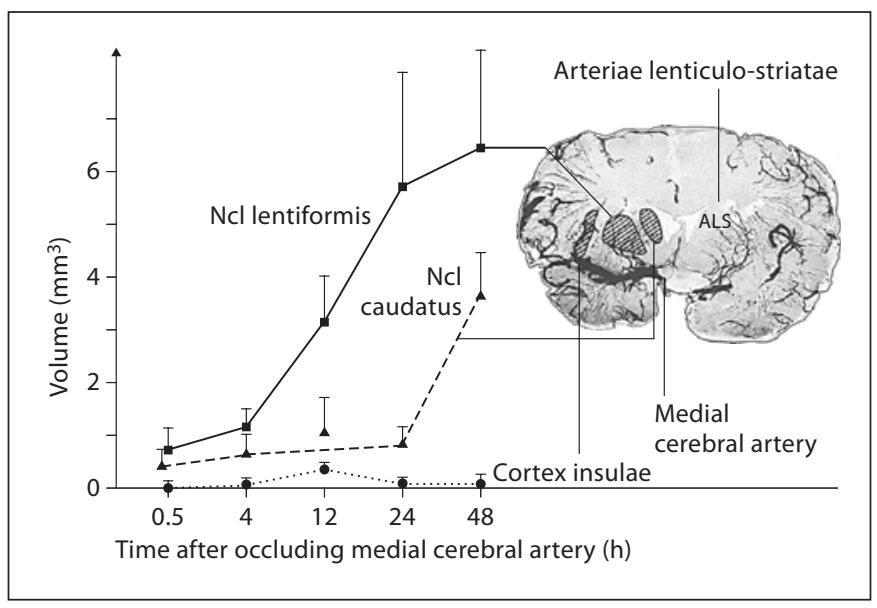

Fig. 15. Morphometric measurement of the time-dependent increase in infarct size. Infarct size is clearly marked by the released acid phosphatase bordering the ischemic area.

Acid phosphatase offers the possibility to objectify the extension of the penumbra by morphometric techniques, which is actually much smaller than expected by X-ray investigation (fig. 16).

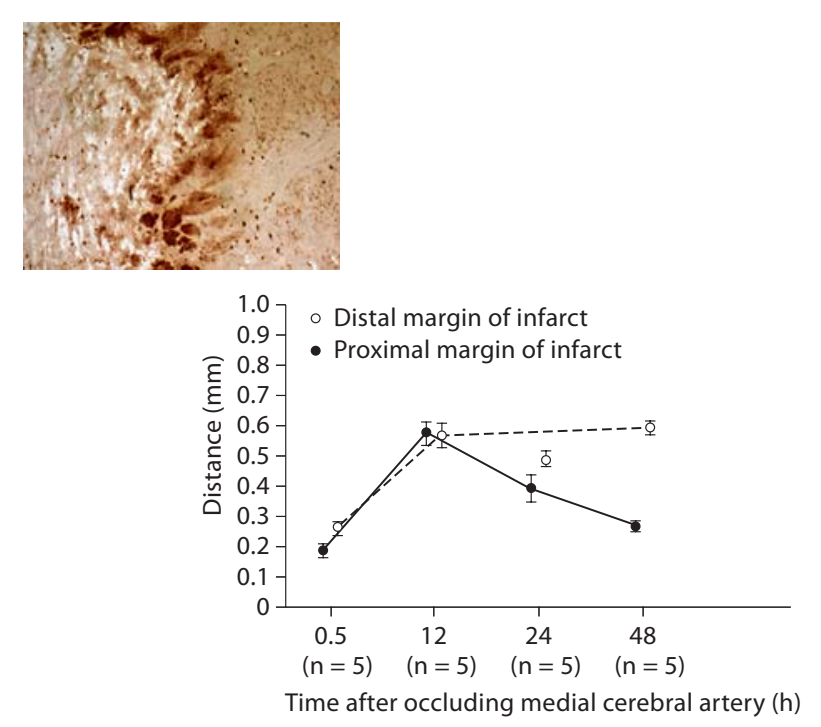

Fig. 16. Morphometry of extension of penumbra of an ischemic brain infarct (nucleus lentiformis). Acid phosphatase. $\times 90$. Acid phosphatase stains the edematous border of the brain infarct. As a consequence of the flow of the cerebrospinal fluid, the edematous border with increased acid phosphatase activity extends more in the direction towards the lateral ventricle than the direction of the cortex.

\section{Performance of Enzyme Histochemistry on Formalin-Fixed and Paraffin-Embedded Tissue}

Enzyme histochemistry is also frequently applied in hematology. Chloroacetate esterase is commonly used as a marker of myelopoiesis. A major advantage of this esterase is its stability to formalin fixation and paraffin embedding. Low levels of chloroacetate esterase in bone marrow smears of patients with promyelocytic leukemia are considered to indicate a bad prognosis [31]. As a nonspecific marker [32], in hematological laboratories it is routinely applied in conjunction with a series of different enzymes as $\beta$-glucuronidase, $\beta$-glucosaminidase, acid phosphatase, peroxidase and a number of dehydrogenases of the citric cycle [33].

Tartrate-resistant acid phosphatase is an enzyme localized to mature osteoclasts $[34,35]$. Tartrate-resistant acid phosphatase is similarly resistant to formalin fixation, paraffin embedding and even EDTA decalcification, and is applied to visualization of osteoclasts in bone biopsies and osteopetrosis after bone marrow transplantation [35]. Serum levels of tartrate-resistant acid phosphatase are determined for monitoring bone metastases 
[36] and in patients with prosthetic hip replacement to predict periprosthetic osteopenia [37].

However, it should be stated that none of these two reactions applicable to formalin-fixed, paraffin-embedded tissue equals the dynamics and stoichiometry of classical enzyme histochemical reactions like lactic dehydrogenase, succinic dehydrogenase, alkaline phosphatase, acid phosphatase, ATPase, glucuronidase and other enzymes.

\section{Conclusion}

Enzyme histotopochemistry is a functional technique providing insights into the pathophysiology and pathobiology of a particular pathological process. It has the po- tential to demonstrate the vitality of cells or a particular tissue. Enzyme histochemistry serves to detect early metabolic changes in biopsy and autopsy tissue before manifestation on HE staining or immunohistochemistry. As such, it constitutes a valuable complement to other special techniques, i.e. immunohistochemistry and molecular pathology.

An exclusive diagnostic domain of enzyme histochemical analysis is the aganglionosis of the distal rectum mucosa, which cannot reliably be diagnosed by conventional histology alone. Apart from current diagnostic applications in muscle biopsy analysis and the diagnosis of Hirschsprung disease, enzyme histochemistry provides access to a wide range of investigations in experimental pathology and toxicology as a pathophysiological supplement to conventional histology.

\section{References}

1 Hardonk MJ, Koudstaal J: Enzyme histochemistry as a link between biochemistry and morphology. Prog Histochem Cytochem 1976;8:1-68.

-2 Patrick WJ, Besley GT, Smith II: Histochemical diagnosis of Hirschsprung's disease and a comparison of the histochemical and biochemical activity of acetylcholinesterase in rectal mucosal biopsies. J Clin Pathol 1980; 33:336-343.

3 Pearse A: Histochemistry, Theoretical and Applied, ed 1. London, Churchill, 1953.

4 Pearse A: Histochemistry, Theoretical and Applied, ed 2. London, Churchill, 1960.

5 Hodel C: Früherfassung des Herzinfarktes mit der Neotetrazoliummethode. Med Lab (Stuttgart) 1965;9:206-209.

6 Hodel C: Untersuchungen an Myokardinfarkten mit der Neotetrazoliummethode. Dtsch Z Gesamte Gerichtl Med 1966;58:3239.

$>7$ Keane R, O’Grady JG, Sheil J, Stevens FM, Egan-Mitchell B, McNicholl B, McCarthy CF, Fottrell PF: Intestinal lactase, sucrase and alkaline phosphatase in relation to age, sex and site of intestinal biopsy in 477 Irish subjects. J Clin Pathol 1983;36:74-77.

-8 Padykula HA, Strauss EW, Ladman AJ, Gardner FH: A morphologic and histochemical analysis of the human jejunal epithelium in nontropical sprue. Gastroenterology 1961; 40:735-765.

9 Spiro HM, Filipe MI, Stewart JS, Booth CC, Pearse AG: Functional histochemistry of the small bowel mucosa in malabsorptive syndromes. Gut 1964;5:145-154.
10 Samloff IM, Davis JS, Schenk EA: A clinical and histochemical study of celiac disease before and during a gluten-free diet. Gastroenterology 1965;48:155-172.

11 Congdon P, Mason MK, Smith S, Crollick A, Steel A, Littlewood J: Small-bowel mucosa in asymptomatic children with celiac disease. Mucosal changes with gluten-free diets. Am J Dis Child 1981;135:118-121.

12 O'Grady JG, Stevens FM, Keane R, Cryan EM, Egan-Mitchell B, McNicholl B, McCarthy CF, Fottrell PF: Intestinal lactase, sucrase, and alkaline phosphatase in 373 patients with coeliac disease. J Clin Pathol 1984;37:298-301.

13 Cammarota G, Cesaro P, La Mura R, Martino A, Cazzato A, Miele L, Lupascu A, Vecchio FM, Larocca LM, Grieco A, Gasbarrini $\mathrm{G}$ : Role of the 'immersion technique' in diagnosing celiac disease with villous atrophy limited to the duodenal bulb. J Clin Gastroenterol 2007;41:571-575.

14 Green PH: Where are all those patients with celiac disease? Am J Gastroenterol 2007;102: 1461-1463.

15 Killander A, Arnell H, Hagenas L, Finkel Y: Omitting control biopsy in paediatric coeliac disease: a follow-up study. Acta Paediatr 2007;96:1190-1194.

16 Unterharnscheidt F: A neurologist's reflection on boxing. V. Concluding remarks. Rev Neurol 1995;23:1027-1032.

17 Fessatidis IT, Thomas VL, Shore DF, Hunt RH, Weller RO, Goodland F, Rowe D, Venetikou MV, Bloom SR: Assessment of neurological injury due to circulatory arrest during profound hypothermia. An experimental study in vertebrates. Eur J Cardiothorac Surg 1993;7:465-472; discussion 473.
18 Hausmann R, Seidl S, Betz P: Hypoxic changes in Purkinje cells of the human cerebellum. Int J Legal Med 2007;121:175-183.

19 Matschke J, Laas R, Schulz F: Cerebellar atrophy following mild head injury in a 4-yearold girl. Pediatr Neurosurg 2007;43:330333.

20 Mathupala SP, Colen CB, Parajuli P, Sloan AE: Lactate and malignant tumors: a therapeutic target at the end stage of glycolysis. J Bioenerg Biomembr 2007;39:73-77.

21 Nakagawa T, Tanaka F, Takata T, Matsuoka K, Miyahara R, Otake Y, Yanagihara K, Fukushimab M, Wada $\mathrm{H}$ : Predictive value of dihydropyrimidine dehydrogenase expression in tumor tissue, regarding the efficacy of postoperatively administered UFT (tegafur + uracil) in patients with p-stage I nonsmallcell lung cancer. J Surg Oncol 2002;81:8792.

22 Landex NL, Thomsen J, Kayser L: Methimazole increases $\mathrm{H}_{2} \mathrm{O}_{2}$ toxicity in human thyroid epithelial cells. Acta Histochem 2006; 108:431-439.

23 Xu RH, Pelicano H, Zhou Y, Carew JS, Feng L, Bhalla KN, Keating MJ, Huang P: Inhibition of glycolysis in cancer cells: a novel strategy to overcome drug resistance associated with mitochondrial respiratory defect and hypoxia. Cancer Res 2005;65:613-621.

24 Pelicano H, Martin DS, Xu RH, Huang P: Glycolysis inhibition for anticancer treatment. Oncogene 2006;25:4633-4646.

-25 Kroemer G: Mitochondria in cancer. Oncogene 2006;25:4630-4632 
-26 El-Bacha T, de Freitas MS, Sola-Penna M: Cellular distribution of phosphofructokinase activity and implications to metabolic regulation in human breast cancer. $\mathrm{Mol} \mathrm{Ge-}$ net Metab 2003;79:294-299.

27 Shaw RJ: Glucose metabolism and cancer. Curr Opin Cell Biol 2006;18:598-608.

28 Ristow M: Oxidative metabolism in cancer growth. Curr Opin Clin Nutr Metab Care 2006;9:339-345.

29 Merida I, Avila-Flores A: Tumor metabolism: new opportunities for cancer therapy. Clin Transl Oncol 2006;8:711-716.

-30 Cao X, Fang L, Gibbs S, Huang Y, Dai Z, Wen P, Zheng X, Sadee W, Sun D: Glucose uptake inhibitor sensitizes cancer cells to daunorubicin and overcomes drug resistance in hypoxia. Cancer Chemother Pharmacol 2007; 59:495-505.

- 31 Chinprasertsuk S, Piankijagum A, Issaragrisil S: Cytochemical stainings in acute promyelocytic leukemia: chloroacetate esterase reaction as a prognostic index. J Med Assoc Thai 1991;74:87-91.

32 Rosenthal NS, Farhi DC: Acute monocytic leukemia with chloroacetate esterase positivity. FAB M4 or M5? Am J Clin Pathol 1992; 98:41-45.

33 Van Noorden CJ, Vogels IM, Van Wering ER: Enzyme cytochemistry of unfixed leukocytes and bone marrow cells using polyvinyl alcohol for the diagnosis of leukemia. Histochemistry 1989;92:313-318.

- 34 Perez-Amodio S, Jansen DC, TigchelaarGutter W, Beertsen W, Everts V: Endocytosis of tartrate-resistant acid phosphatase by osteoblast-like cells is followed by inactivation of the enzyme. Calcif Tissue Int 2006;78: 248-254.

- 35 Bruder E, Stallmach T, Peier K, Superti-Furga A, Vezzoni P: Osteoclast morphology in autosomal recessive malignant osteopetrosis due to a TCIRG1 gene mutation. Pediatr Pathol Mol Med 2003;22:3-9.

- 36 Honig A, Rieger L, Kapp M, Krockenberger M, Eck M, Dietl J, Kammerer U: Increased tartrate-resistant acid phosphatase (TRAP) expression in malignant breast, ovarian and melanoma tissue: an investigational study. BMC Cancer 2006;6:199.

- 37 Habermann B, Eberhardt C, Feld M, Zichner L, Kurth AA: Tartrate-resistant acid phosphatase 5b (TRAP 5b) as a marker of osteoclast activity in the early phase after cementless total hip replacement. Acta Orthop 2007; 78:221-225.

38 Meier-Ruge W, Bielser W Jr, Wiederhold KH, Meyenhofer M: Incubation media for routine laboratory work on enzyme histotopochemistry. Beitr Pathol 1971;144:409-431.

39 Meier-Ruge W: Anwendung und Aussagewert der Fermenthistochemie in der speziellen und experimentellen Pathologie. Med Lab (Stuttgart) 1965;18:192-198, $215-$ 225.
40 Meier-Ruge WA, Bruder E: Pathology of chronic constipation in pediatric and adult coloproctology. Pathobiology 2005;72:1102.

41 Lojda G, Schiebler TH: Enzyme Histochemistry: A Laboratory Manual. Berlin/Heidelberg, Springer, 1979.

42 Pearse A: Histochemistry, Theoretical and Applied, ed 3. London, Churchill, 1968.

43 Meier-Ruge WA, Bruder E: Methodology of enzyme histochemistry in coloproctological motility disorders. Pathobiology 2005;72: 91-99.

44 Stoss FWM-R, Knecht NA, Müller-Lobeck $\mathrm{H}$, Ammann K: Atrophic hypoganglionosis in the colon of adults with slow-transit constipation: a morphometric histopathological investigation. Eur Surg 2005;37:87-93.

45 Landman GB: A five-year chart review of children biopsied to rule out Hirschsprung's disease. Clin Pediatr (Phila) 1987;26:288291

46 Park WH, Choi SO, Kwon KY, Chang ES: Acetylcholinesterase histochemistry of rectal suction biopsies in the diagnosis of Hirschsprung's disease. J Korean Med Sci 1992;7:353-359.

47 Nakao M, Suita S, Taguchi T, Hirose R, Shima Y: Fourteen-year experience of acetylcholinesterase staining for rectal mucosal biopsy in neonatal Hirschsprung's disease. J Pediatr Surg 2001;36:1357-1363.

-48 De Lorijn F, Reitsma JB, Voskuijl WP, Aronson DC, Ten Kate FJ, Smets AM, Taminiau JA, Benninga MA: Diagnosis of Hirschsprung's disease: a prospective, comparative accuracy study of common tests. J Pediatr 2005; 146:787-792.

49 Meier-Ruge W: Ultrashort segment Hirschsprung disease. An objective picture of the disease substantiated by biopsy (in German). Z Kinderchir 1985;40:146-150.

50 Meier-Ruge W, Schärli AF: The epidemiology and enzyme histotopochemical characterization of ultra-short Hirschsprung's disease. Pediatr Surg Int 1986;1:37-42.

51 Ballard ET: Ultrashort segment Hirschsprung's disease: a case report. Pediatr Pathol Lab Med 1996;16:319-325.

-52 Meier-Ruge WA, Bruder E: Histopathology of ultrashort Hirschsprung's disease and aganglionic musculus corrugator cutis ani. Pathobiology 2005;72:26-29.

53 Feszt G, Feszt T, Almassi S: The effect of neuroplegic substances on the activity of alkaline phosphatase in the liver of rats in conditions of burn shock. Biull Eksp Biol Med 1960;49:78-81.

54 Nedwich A, Sokolic IH, Foreman J, Howard JM: Histochemical observations of seconddegree burns. J Trauma 1964;4:269-281.

55 Rondez R, Ruettner JR: On the pathology of jaundice. Enzyme histochemical studies on the behavior of the bile capillaries after experimental icterogenic liver damage. Pathol Microbiol (Basel) 1963;26:784-796.
56 Cavallero C, Turolla E, Carnevali L, Finardi G, Pedini G: Enzyme histochemistry in liver pathology. Pathol Eur 1972;7:4-16.

-57 Hagerstrand I: Bile canalicular alkaline phosphatase in necropsy specimens of the liver and its relation to disease. Acta Pathol Microbiol Scand (A) 1976;84:278-284.

58 Kautzsch E: Enzyme histotopography of the liver. 1 . The histochemical detectable alkaline phosphatase of the liver and its behavior in infectious hepatitis. Med Klin 1964;59: 1501-1505.

-59 Barakat M, Grubb MN, Goyal RK, Hersh T: Intestinal alkaline phosphatase in patients with liver disease. Am J Dig Dis 1971;16: 1102-1106.

60 Petzold H, Rogos R: Biopsy enzyme-histochemical findings in the diagnosis of liver diseases. Dtsch Z Verdau Stoffwechselkr 1974;34:301-305

61 Mysik M, Szczudrawa J: Correlation of liver function and morphological abnormalities in mitral stenosis. Pol Med Sci Hist Bull 1975; 15:439-446.

62 Hunziker O, Emmenegger H, Frey H, Schulz U, Meier-Ruge W: Morphometric characterization of the capillary network in the cat's brain cortex: a comparison of the physiological state and hypovolemic conditions. Acta Neuropathol 1974;29:57-63.

63 Wiederhold KH, Bielser W Jr, Schulz U, Veteau MJ, Hunziker O: Three-dimensional reconstruction of brain capillaries from frozen serial sections. Microvasc Res 1976;11:175180.

64 Zimmermann H: Experimentelle histologische, histochemisch-funktionelle Untersuchungen zur Frage der Nierenschädigung nach temporärer Ischämie. Beitr Pathol Anat 1957;117:65-84.

65 Geyer G: Histochemischer Nachweis funktioneller Veränderungen an Tubulusepithelzellen in der Niere der Maus. Acta Histochem (Jena) 1960;10:1-10.

66 Meier-Ruge W: Der Magnesium-Chinaldin Komplex als nephrotoxisches Wirkungsprinzip halogenierter Chinolinderivate. Z Ges Exper Med 1964;138:99-101.

-67 Meier-Ruge WA, Brunner LA, Engert J, Heminghaus M, Holschneider AM, Jordan P, Piket G, Posselt HG, Scharli A: A correlative morphometric and clinical investigation of hypoganglionosis of the colon in children. Eur J Pediatr Surg 1999;9:67-74.

68 Meier-Ruge WA, Brunner LA: Morphometric assessment of Hirschsprung's disease: associated hypoganglionosis of the colonic myenteric plexus. Pediatr Dev Pathol 2001;4: 53-61.

69 Bruder E, Meier-Ruge WA: Hypoganglionosis as a cause of chronic constipation (in German). Pathologe 2007;28:131-136.

70 Moreno-Sanchez R, Rodriguez-Enriquez S, Marin-Hernandez A, Saavedra E: Energy metabolism in tumor cells. FEBS J 2007;274: 1393-1418. 
71 Wu M, Neilson A, Swift AL, Moran R, Tamagnine J, Parslow D, Armistead S, Lemire K, Orrell J, Teich J, Chomicz S, Ferrick DA: Multiparameter metabolic analysis reveals a close link between attenuated mitochondrial bioenergetic function and enhanced glycolysis dependency in human tumor cells. Am J Physiol Cell Physiol 2007;292:C125-C136.

72 Betz AL, Firth JA, Goldstein GW: Polarity of the blood-brain barrier: distribution of enzymes between the luminal and antiluminal membranes of brain capillary endothelial cells. Brain Res 1980;192:17-28.

73 Vorbrodt AW, Lossinsky AS, Wisniewski HM: Enzyme cytochemistry of blood-brain barrier (BBB) disturbances. Acta Neuropathol Suppl 1983;8:43-57.
74 Omar R, Pappolla M, Argani I, Davis K: Acid phosphatase activity in senile plaques and cerebrospinal fluid of patients with Alzheimer's disease. Arch Pathol Lab Med 1993; 117:166-169.

75 Meier-Ruge W: Drug induced retinopathy. Ophthalmologica 1969;158(suppl):561-573.

76 Meier-Ruge W: Experimental investigation of the morphogenesis of chloroquine retinopathy. Arch Ophthalmol 1965;73:540544.

77 Meier-Ruge W: Drug induced retinopathy. CRC Crit Rev Toxicol 1992;1:325-360.

78 Meier-Ruge W, Bruder A, Theodore D: Histochemical and morphometric investigation of the pathogenesis of acute brain infarction in primates. Acta Histochem Suppl 1992;42: 59-70.
79 Lageron A, Leponcin-Lafitte M, Rapin JR, Saffroy M, Bulach C: Brain rat histoenzymological changes induced by microsphere injection during ischemia. Acta Histochem 1979;64:184-190.

80 Chiamulera C, Terron A, Reggiani A, Cristofori P: Qualitative and quantitative analysis of the progressive cerebral damage after middle cerebral artery occlusion in mice. Brain Res 1993;606:251-258.

81 Meier-Ruge W: The Pathophysiology of Stroke - Causes and Mechanisms of Cerebral Infarction. Basel, Karger, 1990.

82 Kadam SD, Dudek FE: Neuropathogical features of a rat model for perinatal hypoxicischemic encephalopathy with associated epilepsy. J Comp Neurol 2007;505:716-737. 